\title{
Analisis Pengaruh Nilai Tukar Rupiah, Suku Bunga Sbi, Inflasi Terhadap Jakarta Islamic Index
}

\author{
${ }^{1 *}$ Harun Santosa, ${ }^{2}$ Ashari Mursito Wisnu \\ ${ }^{1,2}$ Sekolah Tinggi Ilmu Ekonomi AAS Surakarta, Indonesia \\ *Email korenpondensi: haruntop@yahoo.com
}

\begin{abstract}
This research was conducted to find out whether there was an influence of the rupiah exchange rate, SBI interest rate, inflation rate on the Jakarta Islamic Index. The study population was the Jakarta Islamic Index with a sample of the Jakarta Islamic Index data for the 2007-2017 period. The method of analysis is done using multiple linear regression. The analysis shows that the rupiah exchange rate and SBI interest rate have a significant effect on the Jakarta Islamic Index, while inflation has no significant effect on the Jakarta Islamic Index. Simultaneously the exchange rate, interest rate and inflation have a significant influence on the Jakarta Islamic Index.
\end{abstract}

Keywords: Jakarta Islamic Index, Rupiah exchange rate, SBI interest rate, Inflation

\begin{abstract}
Abstrak
Penelitian ini dilakukan untuk mengetahui apakah terdapat pengaruh nilai tukar rupiah, tingkat suku Bunga SBI, tingkat inflasi terhadap Jakarta Islamic Index. Populasi penelitian adalah Jakarta Islamic Index dengan sampel penelitian data Jakarta Islamic Index periode 2007-2017. Metode analisis dilakukan dengan menggunakan regresi linier berganda. Hasil analisis menunjukkan nilai tukar rupiah dan tingkat suku bunga SBI berpengaruh signifikan terhadap Jakarta Islamic Index, sedangkan inflasi tidak berpengaruh signifikan terhadap Jakarta Islamic Index. Secara simultan kurs, tingkat suku bunga dan inflasi perpengaruh signifikan terhadap Jakarta Islamic Index.
\end{abstract}

Kata kunci: Jakarta Islamic Index, Nilai tukar rupiah, Suku bunga SBI, inflasi

Saran sitasi: Santosa, H., \& Wisnu, A. (2018). Analisis Pengaruh Nilai Tukar Rupiah, Suku Bunga SBI, Inflasi Terhadap Jakarta Islamic Index. Jurnal Ilmiah Ekonomi Islam, 4(03), 160-167. doi:http://dx.doi.org/10.29040/jiei.v4i03.295

DOI: http://dx.doi.org/10.29040/jiei.v4i03.295

\section{Pendahuluan}

Pasar modal syariah merupakan salah satu alternatif investasi dengan saham syariah sebagai instrumen investasi yang menyatakan bukti penyertaan kepemilikan dalam perusahaanperusahaan yang berbasis syariah. Tandelilin (2011) mengemukakan investasi bisa didefinisikan sebagai komitmen sejumlah uang atau sumber daya lainnya yang dilakukan saat ini (present time) dengan harapan memperoleh manfaat (benefit) dikemudian hari (in future).

Bagi sebagian masyarakat bahwa indikator ekonomi makro seperti PDB, inflasi, tingkat bunga dan nilai tukar mata uang bisa membantu investor dalam meramalkan apa yang akan terjadi pada perubahan pasar modal. Misalnya tingkat bunga SBI bisa dipakai dalam meramalkan harga saham atau obligasi yang akan 
terjadi. Jika investor meramalkan tingkat suku bunga akan meningkat, maka investor bisa memperkirakan bahwa harga obligasi maupun harga saham akan cenderung menurun. Kemampuan investor dalam memahami dan meramalkan kondisi ekonomi makro di masa datang,akan sangat berguna dalam pembuatan keputusan investasi yang menguntungkan (Tandelilin, 2011 ).

Jakarta Islamic Index (JII) sendiri merupakan kelompok saham yang memenuhi kriteria investasi syariah Islam dalam pasar modal Indonesia. Saham syariah yang menjadi konstituen JII terdiri dari 30 saham yang merupakan saham - saham syariah paling likuid dan memiliki kapitalisasi pasar yang besar Banyak teori dan penelitian terdahulu yang dilakukan Kewal (2012) dan Jatiningsih \& Musdholifah.(2007) menunjukkan hasil kurs pengaruh negatif danberbeda dengan Kandir (2008) untuk variabel kurs pengaruh berpengaruh positif terhadap saham Sedangkan variabel inflasi menurut penelitian Erdem ,et al.(2005) dan Rusliati \& Fathoni (2011), berpengaruh negatif. Menurut Mulyani (2014) inflasi berpengaruh positif, sedangkan suku bunga dan nilai tukar rupiah berpengaruh negatif terhadah Jakarta Islamic Index.

\section{Metode Penelitian}

Desain penelitian merupakan proses memikirkan dan mempersiapkan penelitian yang akan dilakukan. Mendesain suatu penelitian berarti menentukan jenis penelitian, menentukan datayang digunakan dan merancang model empiris untuk menguji hipotesis secara statistik (Sekaran, 2011). Penelitian tentang analisis pengaruh nilai tukar rupiah, tingkat suku bunga SBI, tingkat inflasi terhadap Jakarta islamic index tahun 2007 -2017 menggunakan metode penelitian deskriptif kuantitatif. Penelitian deskriptif merupakan dasar bagi semua penelitian. Penelitian deskriptif dapat dilakukan secara kuantitatif agar dapat dilakukan analisis statistic.

Dalam penelitian ini variabel dependen adalah indek harga saham JII pada saat penutupan akhir tahun. indek harga saham JII digunakan dalam menganalisis data adalah hasil yang diperoleh dari harga saham penutupan pada akhir bulan di http://www.duniainvestasi.com.

Dalam penelitian ini variabel Independen/ Variabel Bebas adalah :

a. Nilai Tukar Rupiah $\left(\mathrm{X}_{1}\right)$, merupakan harga di dalam pertukaran dan dalam pertukaran antara dua macam mata uang yang berbeda, akan terdapat perbandingan nilai atau harga antara kedua mata uang tersebut. Pengukurannya berdasarkan perbandingan nilai tukar dollar terhadap rupiah yang dihitung secara bulanan yang diumumkan pemerintah dengan satuan rupiah per US Dollar. Data yang digunakan dalam penelitian ini diambil dari Kurs Jual yang diambil bulanan mulai dari Januari 2007 - Desember 2017

b. Tingkat Suku Bunga $\left(\mathrm{X}_{2}\right)$, merupakan Suku Bunga kebijakan yang mencerminkan sikap kebijakan moneter yang ditetapkan oleh bank Indonesia dan diumumkan kepada publik sebagai pengakuan utang berjangka waktu pendek. Suku Bunga yang digunakan dalam penelitian ini merupakan Suku Bunga. Pengukuran yang digunakan adalah satuan persentase dan data yang diambil adalah Suku Bunga SBI per bulan mulai Januari 2007 - Desember 2017.

c. Inflasi $\left(\mathrm{X}_{3}\right)$, merupakan suatu tingkat yang terjadi pada penutupan tahun. Data Inflasi merupakan data dari Bank Indonesia (BI). Inflasi $\left(\mathrm{X}_{3}\right)$ adalah kecenderungan terjadinya peningkatan harga produk secara keseluruhan (Tandelilin, 2011). Data Inflasi yang dipergunakan dalam penelitian ini adalah data inflasi berdasarkan perhitungan inflasi bulanan Januari 2007 - Desember 2017

Populasi adalah semua nilai baik hasil perhitungan maupun pengukuran, baik kuantitatif maupun kualitatif, daripada karakteristik tertentu mengenai sekelompok obyek yang lengkap dan jelas (Usman \& Akbar, 2003). Adapun populasi dalam penelitian ini adalah semua data tentang nilai tukar rupiah, tingkat suku bunga SBI dan tingkat inflasi dan indek JII. Penelitian dilak- 
sanakan selama 7 Tahun dari Bulan Januari 2007 sampai Desenber 2017.

Sampel adalah subset dari populasi yang terdiri dari beberapa anggota populasi (Ferdinand, 2012). Pada penentuan sampel dan populasi pada penelitian ini adalah nilai tukar rupiah, tingkat suku bunga SBI dan tingkat inflasi dan indek JII yang tercatat di Bank Indonesia dan IDX dari Tahun 2007 sampai dengan tahun 2017.

Metode pengambilan sampel yang digunakan adalah metode purposive Sampling. Adapun kriteria dalam pengambilan sampel sebagai berikut :

a. Nilai tukar, suku bunga SBI dan Inflasi diakses di http://www.bi.go.id

b. Jakarta Islamic Index diakses di http://www.duniainvestasi.com

Jadi Jumlah perusahaan yang dijadikan sampel dan memenuhi kriteria dalam pengambilan sampel di atas diperoleh total sampel selama tujuh tahun yaitu 132 observasi.

Jenis data yang digunakan pada penelitian ini adalah data sekunder, yang berarti bahwa data yang ada tidak didapatkan dengan melakukan observarsi atau penelitian langsung kepada objek yang menjadi penelitian.

Sumber data yang digunakan untuk penelitian ini diperoleh dari situs resmi Jakarta Islamic Index (JII) yaitu http://www.duniainvestasi.com, Situs resmi Bank Indonesia yaitu www.bi.go.id, dan Pusat Referensi Pasar Modal (PRPM)

a. Teknik Pengumpulan Data.

Pengumpulan data yang digunakan dalam penelitian ini diperoleh melalui 2 cara yaitu :

1) Studi dokumentasi, merupakan teknik pengumpulan data yang tidak langsung ditujukan kepada subjek penelitian. Dokumen dapat dibedakan menjadi dokumen primer (dokumen yang ditulis oleh orang yang langsung mengalami suatu peristiwa), dan dokumen sekunder (jika peristiwa dilaporkan kepada orang lain yang selanjutnya ditulis oleh orang lain). Ketika menggunakan metode ini sebagai metode pengumpulan data, maka peneliti bisa menggunakan data yang ada dengan hanya membuat salinan atau menggandakanya.

2) Penelitian Kepustakaan (Library Research). Metode ini dilakukan dengan cara mengumpulkan bahan atau data-data yang berhubungan dengan objek yang akan diteliti. Metode ini bisa dilakukan dengan cara mengkaji, mempelajari serta menelah berbagai macam literatur seperti buku, jurnal, koran, dan berbagai sumber tertulis lainnya yang berkaitan dengan objek yang akan diteliti.

Metode Analisis Data, Metode analisis data yang digunakan dalam penelitian ini antara lain adalah analisis statistik deskriptif, uji asumsi klasik, dan pengujian hipotesis. Data yang diolah akan dilakukan pengujian statistik dengan menggunakan SPSS 20 for Windows, untuk menguji hipotesis yang telah dirumuskan, maka dalam penelitian ini digunakan metode analisis data sebagai berikut:

a) Analisis Statistik Deskriptif.

Statistik deskriptif memberikan gambaran atau deskriptif suatu data yang dilihat dari nilai rata-rata (mean), standar deviasi, varian nilai maksimum ( $\max$ ), nilai minimum ( $\min$ ), sun, range, kurtosis dan skewness. Mean digunakan untuk meperkirakan besar rata-rata populasi yang diperkirakan dari sampel.

Standar deviasi digunakan untuk menilai disperse rata-rata dari sampel. Maksimumminimum digunakan untuk melihat nilai minimum dan maksimum dari populasi. Hal ini perlu dilakukan untuk melihat gambaran keseluruhan dari sampel yang berhasil dikumpulkan dan memenuhi syarat.

Analisis statistik deskriptif digunakan untuk mengetahui gambaran mengenai tingkat Inflasi, Suku bunga, Nilai tukar rupiah dan indek harga saham pada Jakarta Islamic Index .

b). Uji Asumsi Klasik

Penelitian ini menggunakan pengujian regresi linier berganda. Regresi linier berganda dapat dilakukan setelah model dari penelitian memenuhi syarat lolos dari Uji Asumsi Klasik. Syarat tersebut adalah data harus terdistribusi 
secara normal, tidak mengandung multikolinieritas, heterokedastisitas, dan autokorelasi.

c). Pengujian hipotesis.

Pengujian hipotesis yang dipakai dalam penelitian ini adalah regresi berganda digunakan untuk menguji pengaruh faktor-faktor nilai tukar rupiah, tingkat suku bunga SBI, tingkat inflasi terhadap indek harga saham Jakarta Islamic Index dengan menggunakan tingkat signifikan $\alpha$ $=5 \%$. Persamaan regresi dalam penelitian ini adalah :

$$
Y=\alpha+\beta_{1} \mathrm{X}_{1}+\beta_{2} \mathrm{X}_{2}+\beta_{3} \mathrm{X}_{3}+e
$$

Keterangan :

$\mathrm{Y}=$ indek harga saham JII.

$\mathrm{a}=$ Harga konstanta (harga $\mathrm{Y}$ bila $\mathrm{X}=0$ )

$\mathrm{b}_{1,2,3}=$ Harga koefisien regresi

$\mathrm{X}_{1}=$ nilai tukar rupiah

$\mathrm{X}_{2}=$ tingkat suku bunga SBI

$\mathrm{X}_{3}=$ tingkat inflasi

$\mathrm{e}=$ standard error

1) Uji Parsial (uji t).

Uji t pada dasarnya menunjukkan seberapa jauh pengaruh satu variabel penjelas/independen secara individual dalam menerangkan variasi variabel dependen (Ghozali, 2013).

Formulasi pengujian $\mathrm{t}$ yaitu; Jika tingkat signifikan $\mathrm{t}<\alpha 5 \%$, maka Ho ditolak, yang berarti variabel independen secara parsial berpengaruh secara signifikan terhadap variabel dependen. Jika tingkat signifikan $\mathrm{t}>\alpha 5 \%$, maka Ho diterima, berarti variabel independen secara parsial tidak berpengaruh secara signifikan terhadap variabel dependen.

2) Uji Simultan (uji F).

Uji F pada dasarnya menunjukkan apakah semua variabel independen atau bebas yang dimasukkan dalam model mempunyai pengaruh secara bersama-sama terhadap variabel indepeden atau terikat (Ghozali, 2013).

Formulasi pengujian $\mathrm{F}$ yaitu; Jika tingkat signifikan $\mathrm{F}<\alpha 5 \%$ maka Ho ditolak, yang berarti variabel independen secara simultan berpengaruh secara signifikan terhadap variabel dependen. Jika tingkat signifikan $\mathrm{F}>\alpha 5 \%$, maka Ho diterima, berarti variabel independen secara bersama-sama tidak berpengaruh secara signifikan terhadap variabel dependen.

3) Koefisien Determinasi $\left(R^{2}\right)$, digunakan untuk mengukur sejauh mana kemampuan model dalam menerangkan variasi variabel dependen (Ghozali, 2013). Nilai $\mathrm{R}^{2}$ berada diantara nol sampai dengan satu. Semakin mendekati nilai satu maka variabel bebas hampir memberikan semua informasi untuk memprediksi variabel terikat atau merupakan indikator yang menunjukkan semakin kuatnya kemampuan dalam menjelaskan perubahan variabel bebas terhadap variasi variabel terikat.

\section{Hasil dan Pembahasan}

\subsection{Hasil Penelitian}

Hasil statistik deskriptif variabel penelitian yang disajikan dalam Tabel 1.

Tabel 1. Hasil Statistik Deskriptif

\begin{tabular}{lrrrr}
\hline & Minimum & Maximum & Mean & Std. Dev \\
\hline Kurs & 8574,79 & 14468,00 & 10859,09 & 1848,03 \\
SBI & 4,25 & 9,50 & 6,85 & 1,25711 \\
Inflasi & 2,41 & 12,14 & 5,77 & 2,2333 \\
JII & 1936829 & 7590700 & $5,4247 \mathrm{E} 6$ & $1,48180 \mathrm{E} 6$ \\
\hline
\end{tabular}

Nilai tukar rupiah terhadap dolar Amerika merupakan kurs tengah mata uang rupiah terhadap mata uang dolar Amerika dengan satuan rupiah, diperoleh dari website resmi dalam kurun waktu bulanan Januari 2007 sampai dengan Desember 2017 besarnya nilai rata-rata kurs sebesar 10.859,09 nilai tertinggi kurs sebesar 14.468,00 dengan kurs terendah 8.574,79 dengan standar deviasi dari rata-rata kurs sebesar $1.848,03$.

Tingkat suku bunga SBI merupakan salah satu faktor penting yang perlu diperhatikan dalam pembuatan keputusan investasi, dalam kurun waktu bulanan Januari 2007 sampai dengan Desember 2017 rata-rata tingkat suku bunga SBI sebesar 6, 85 tingkat suku bunga SBI tertinggi sebesar 9,50 dengan tingkat suku bunga SBI terendah 4,25 dengan standar deviasi dari rata-rata tingkat suku bunga SBI sebesar 1,25711. 
Inflasi yang digunakan dalam penelitian ini adalah laju inflasi indeks harga konsumen bulanan yang dikeluarkan oleh BPS dari Januari 2007 sampai dengan Desember 2017 rata-rata laju inflasi sebesar 5,77 laju inflasi tertinggi sebesar 12,14 dengan laju inflasi terendah 2,41 dengan standar deviasi dari rata-rata sebesar 2,2333.

Indek harga saham JII pada hari penutupan (closing date) selama periode Januari 2007 sampai dengan Desember 2017 diperoleh dari IDX Quaterly Report Bursa Efek Indonesia melalui website resminya. Besarnya nilai ratarata Indek harga saham JII sebesar 5.424.706 Nilai tertinggi Indek harga saham JII sebesar 75.907.00.00 dengan Indek harga saham JII terendah 1.936.829.00 dengan standar deviasi dari rata-rata Indek harga saham JII sebesar 1,4818 .

Tabel 2 Uji Normalitas

\begin{tabular}{lc}
\hline & $\begin{array}{c}\text { Unstandardized } \\
\text { Residual }\end{array}$ \\
\hline Kolmogorov-Smirnov Z & 1,098 \\
Asymp. Sig. (2-tailed) & 0,179 \\
\hline
\end{tabular}

Dari hasil pengujian One Sample Kolmogorov-Smirnov Test diketahui bahwa nilai Asymp. Sig. (2-tailed) adalah 0,2 lebih besar dari signifikansi $\alpha 0,05$ yang berarti data residual berdistribusi normal.

Tabel 3. Uji Autokorelasi.

\begin{tabular}{lr}
\hline & $\begin{array}{c}\text { Unstandardized } \\
\text { Residual }\end{array}$ \\
\hline$Z$ & $-9,087$ \\
Asymp. Sig. (2-tailed) & 0,000 \\
\hline
\end{tabular}

Dari Uji Autokorelasi pada Tabel 3, menunjukkan nilai Asymp. Sig. (2-tailed)sebesar 0,000 lebih kecil dari signifikansi a 0,05 maka hipotesis nol (Ho) ditolak yang berarti bahwa terjadi autokorelasi dan residual bersifat random.

\begin{tabular}{|c|c|c|}
\hline \multirow{2}{*}{ Model } & \multicolumn{2}{|c|}{ Collinearity Statistics } \\
\hline & Tolerance & $V I F$ \\
\hline Kurs & 0.939 & 1.065 \\
\hline SBI & 0.469 & 2.132 \\
\hline Inflasi & 0.487 & 2.055 \\
\hline
\end{tabular}

Dari Tabel 4, dapat dilihat bahwa nilai Tolerance untuk masing-masing variabel tidak kurang dari 0,1 dan Variance Inflation Factor (VIF) untuk masing-masing variabel adalah kurang dari 10 sehingga hal ini membuktikan bahwa model regresi yang digunakan dalam penelitian ini tidak terdapat gejala multikolinearitas.

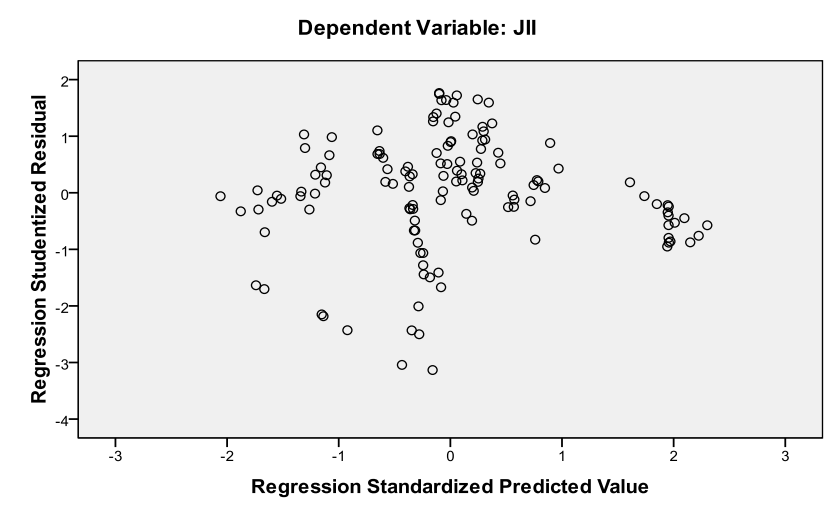

Gambar 1. Uji heterokedastisitas /Scatterplot

Dari hasil Scatterplot diatas terlihat bahwa data menyebar secara acak atau tidak membentuk sebuah pola tertentu, serta titik-titiknya menyebar diatas dan dibawah angka 0 pada sumbu Y, dengan demikian disimpulkan bahwa model yang digunakan dalam penelitian ini tidak terjadi heterokedastisitas dan memenuhi asumsi klasik.

\section{Analisis Regresi Berganda}

Berdasarkan perhitungan regresi berganda antara nilai tukar rupiah terhadap dolar Amerika, Tingkat suku bunga SBI, laju inflasi dan Indek harga saham JII dengan menggunakan program SPSS 20, diperoleh hasil sebagai berikut:

Tabel 5. Hasil Regresi Linier Berganda

\begin{tabular}{|c|c|c|c|c|}
\hline \multirow[t]{2}{*}{ Model } & \multicolumn{2}{|c|}{$\begin{array}{c}\text { Unstandardized } \\
\text { Coefficients }\end{array}$} & \multirow[t]{2}{*}{$t$} & \multirow[t]{2}{*}{ Sig. } \\
\hline & B & Std. Error & & \\
\hline (Constant) & 5967654,029 & 769344,641 & 7,757 & 0,000 \\
\hline Kurs & 359,172 & 45,146 & 7,956 & 0,000 \\
\hline SBI & $-657254,738$ & 93897,313 & $-7,000$ & 0,000 \\
\hline Inflasi & 11117,969 & 51889,744 & 0,214 & 0,831 \\
\hline
\end{tabular}

Dari hasil perhitungan Tabel 5, dapat disajikan dalam bentuk persamaan regresi

$J I I=5967654,029+359,172$ Kurs $-657254,738$ SBI + 11117,969 Inflasi 
Dengan Interpretasi: a = 5967654,029 bahwa dari persamaan tersebut dapat diketahui bahwa rata-rata JII tanpa dipengaruhi oleh variabel apapun adalah sebesar 5967654,029 satuan. $b_{1}=$ 359,172 Artinya, setiap kenaikan kurs sebesar 1 satuan, maka rata-rata JII akan naik sebesar 359,172 satuan dengan menganggap variabel lain konstan. $\quad b_{2}=-657254,738$ artinya, setiap kenaikan tingkat suku bunga SBI sebesar 1 satuan, maka rata - rata JII akan turun sebesar 657254,738 satuan dengan menganggap variabel lain konstan. $b_{3}=11117,969$ artinya, setiap kenaikan tingkat inflasi sebesar 1 satuan, maka rata-rata JII akan naik sebesar 11117,969 satuan dengan menganggap variabel lain konstan.

Uji Signifikan Parameter Individual (Uji-t Statistik)

Uji statistik $\mathrm{t}$ dimaksudkan untuk mengetahui variance koefisien regresi secara parsial atau sendiri-sendiri dalam model yang digunakan. Analisis ini digunakan untuk menguji pengaruh masing-masing variabel independen secara individual dalam menerangkan variabel dependen. Hipotesa yang digunakan dalam uji ini adalah sebagai berikut:

$\mathrm{H}_{0}$ : Variabel independen tidak berpengaruh pada variabel dependen.

$\mathrm{H}_{\mathrm{A}}$ : Variabel independen berpengaruh pada variabel dependen

Dengan tingkat signifikan $(\alpha)$ sebesar 5\%, maka kriteria yang digunakan untuk melakukan uji $\mathrm{t}$ sebagai berikut: Jika signifikansi $\mathrm{t}<\alpha$, berarti $\mathrm{H}_{0}$ ditolak dan Jika signifiknsi $\mathrm{t}>\alpha$, berarti $\mathrm{H}_{0}$ diterima. Hasil perhitungan uji $\mathrm{t}$ dengan menggunakan SPSS 20 untuk menguji pengaruh variabel Kurs, SBI, Inflasi terhadap variabel Indek harga saham JII sebagai berikut:

\section{Uji hipotesis nilai tukar rupiah terhadap Indek harga saham JII}

$\mathrm{H}_{1}$ : nilai tukar rupiah berpengaruh positif dan signifikan terhadap Indek harga saham JII Variabel nilai tukar rupiah $\mathrm{t}$ hitung sebesar 7.956 sedangkan $\mathrm{t}$ tabel pada tingkat keyakinan 5\% adalah 1.960 (7.956 > 1.960). Karena t hitung > t tabel maka H0 ditolak. Dengan demikian daerah penerimaan hipotesis berada diluar daerah penerimaan H0. Dari hasil perhitungan yang diperoleh signifikasi $t$ untuk variabel nilai tukar rupiah sebesar $0.000<\alpha(0,05)$. Hal ini berarti nilai tukar rupiah berpengaruh positif dan signifikan terhadap Indek harga saham JII. Berarti $\mathrm{H}_{1}$ diterima dan Ho ditolak.

\section{Uji hipotesis tingkat suku bunga SBI} berpengaruh terhadap Indek harga saham JII

$\mathrm{H}_{2}$ : tingkat suku bunga berpengaruh positif dan signifikan terhadap Indek harga saham JII

Dari hasil perhitungan yang diperoleh signifikasi $t$ untuk variabel tingkat suku bunga SBI $0.000<\alpha(0,05)$. Hal ini berarti tingkat suku bunga SBI berpengaruh signifikan terhadap Indek harga saham JII. Berarti $\mathrm{H}_{2}$ diterima dan Ho ditolak

\section{Uji hipotesis Inflasi berpengaruh terhadap} Indek harga saham JII

$\mathrm{H}_{3}$ : Inflasi berpengaruh positif dan signifykan terhadap Indek harga saham JII

Dari hasil perhitungan diperoleh signifikasi t untuk variabel inflasi sebesar 0,214> $\alpha(0,05)$. Hal ini berarti inflasi tidak berpengaruh signifikan terhadap Jakarta Indek harga saham JII. Berarti H3 ditolak dan Ho diterima.

\section{Uji F}

Untuk mengetahui tingkat signifikansi pengaruh variabel-variabel independen secara bersama-sama (simultan) terhadap variabel dependen dilakukan dengan menggunakan uji $\mathrm{F}$ test yaitu dengan cara membandingkan antara $\mathrm{F}$ hitung dengan $\mathrm{F}$ tabel, atau membandingkan antara signifikansi $\mathrm{F}$ dengan $\alpha=5 \%$

Tabel 6. Tabel Uji F

\begin{tabular}{lcccc}
\hline Model & $\begin{array}{c}\text { Sum of } \\
\text { Squares }\end{array}$ & $d f$ & $F$ & Sig. \\
\hline Regression & 1,781000000 & 3 & 69.336 & $0.000^{\mathrm{a}}$ \\
\hline
\end{tabular}

Dari hasil perhitungan statistik menggunakan SPSS 20 yang tertera pada Tabel 6, diperoleh nilai $F$ hitung sebesar 69,336 dengan tingkat signifikansi 0,000 . Nilai signifikansi yang dihasilkan tersebut lebih kecil dari $\alpha=0,05$. Hal ini berarti bahwa variabel kurs, SBI dan variabel inflasi secara simultan berpengaruh signifikan terhadap variabel Indek harga saham JII. 


\section{Koefisien Determinasi}

Koefisien determinasi digunakan untuk mengetahui seberapa besar pengaruh variabelvariabel bebas (independen) dapat menjelaskan variasi variabel terikatnya (dependen).

Dari hasil perhitungan dengan program SPSS yang nampak dalam Tabel 7, dapat diketahui bahwa koefisien determinasi yang dapat dilihat dari Adjusted $R$ Square, diperoleh sebesar 0,61 . Hal ini berarti $61 \%$ Indek harga saham JII dapat dijelaskan oleh variabel kurs, SBI dan inflasi. Sedangkan sisanya 39\% dijelaskan oleh variabel-variabel lainnya yang tidak diteliti dalam penelitian ini.

Tabel 7. Tabel Uji Koefisien Determinasi

\begin{tabular}{crrr} 
Model & $\mathrm{R}$ & $\begin{array}{c}R \\
\text { Square }\end{array}$ & $\begin{array}{c}\text { Adjusted } R \\
\text { Square }\end{array}$ \\
\hline 1 & $0,787^{\mathrm{a}}$ & 0,619 & 0,610 \\
\hline
\end{tabular}

Kurs memberikan pengaruh secara signifikan terhadap pergerakan Indek harga saham JII yang berarti hal ini mendukung penelitian Azzam (2002) yang memberikan kesimpulan ada kausalitas (hubungan) dua arah antara kurs terhadap stock price. Hasil ini sejalan dengan teori yang menjelaskan bahwa kurs rupiah dengan kurs mata uang asing akan mempengaruhi harga saham emiten (Jatiningsih \& Musdholifah, 2007;Kandir, 2008). Hal ini bisa dijelaskan sebagai berikut: kurs rupiah akan mempengaruhi penjualan perusahaan (terutama untuk emiten yang berorientasi bisnis ekspor), Cost Of Good Sold (mempengaruhi pembelian bahan baku apabila diperoleh dari impor), dan rugi kurs. Khusus untuk rugi kurs, terutama bagi perusahaan yang memiliki kewajiban dalam mata uang asing, akan sangat terpengaruh oleh depresiasi maupun apresiasi rupiah. Menurunnya nilai tukar rupiah terhadap mata uang asing (dolar Amerika) berdampak terhadap meningkatnya biaya impor bahan baku dan peralatan yang dibutuhkan perusahaan sehingga mengakibatkan meningkatnya biaya produksi, atau dengan kata lain melemahnya nilai tukar rupiah terhadap US Dollar memiliki pengaruh negatif terhadap ekonomi nasional yang pada akhirnya menurun- kan kinerja saham di pasar saham, akan tetapi bertentangan dengan temuan penelitian Mauliano (2009) yang menyimpulkan nilai Kurs tidak berpengaruh terhadap IHSG yang mengambil data periode bulanan 2007-2017.

Dari koefisien regresi variabel Kurs sebesar 359,172 artinya apabila Kurs (\$) meningkat 1 poin, maka pergerakan Indek harga saham JII akan naik sebesar 359,172 poin, dengan kata lain bila ada penguatan nilai tukar (\$) sebesar 1 berpengaruh secara langsung terhadap Indek harga saham JII meningkat 359,172. keadaan ini memudahkan investor menggunakan informasi nilai tukar mata uang dalam dalam membuat keputusan investasi karena adanya pola yang kuat antara kedua variabel tersebut saling mempengaruhi, dan dapat dijelaskan bahwa dollar (\$) menjadi dasar pertimbangan bagi investor dalam membuat keputusan investasi saham, ada kemungkinan dalam sampel penelitian ini adalah investor asing. Temuan sejalan dengan teori pasar modal, yang menganggap apabila nilai uang (kurs) berubah investor cenderung pindah dari saham ke valuta, dan sebaliknya.

Hasil penelitian ini menunjukkan variabel SBI berpengaruh signifikan terhadap variabel Indek harga saham JII, sejalan dengan penelitian Hussin, et al. (2012), Mulyani (2014) bahwa suku bunga berpengaruh terhadap indek saham.

Hasil penelitian ini menunjukkan variabel Inflasi tidak berpengaruh signifikan terhadap variabel Indek harga saham JII. Hasil tersebut tidak sejalan dengan penelitian yang dilakukan oleh Hussin, et al. (2012), Mulyani (2014) bahwa inflasi inflasi berpengaruh positif dan Erdem ,et al (2005), Rusliati \& Fathoni (2011) inflasi berpengaruh negatif terhadap harga saham.

Secara simultan variabel kurs, SBI dan inflasi perpengaruh signifikan terhadap Indek harga saham JII. Hal ini memberikan kesimpulan yang mendukung penelitian Hasibuan (2009) dimana nilai tukar dan harga saham global berpengaruh terhadap pergerakan IHSG 


\section{Kesimpulan}

Berdasakan analisis data dapat disimpulkan bahwa Nilai tukar rupiah berpengaruh terhadap pergerakan Indek harga saham JII berpengaruh secara signifikan. Tingkat suku bunga SBI berpengaruh signifikan terhadap variabel Indek harga saham JII. Inflasi tidak berpengaruh signifikan terhadap variabel Indek harga saham JII. Secara simultan variabel kurs, SBI dan inflasi perpengaruh signifikan terhadap Indek harga saham JII.

\section{Ucapan Terimakasih}

Terima Kasih kepada penyandang dana hibah skim PDP oleh DRPM Ristekdikti pada periode tahun 2017

\section{Daftar Pustaka}

Azzam, H.T., (2002). There's considerable rationale to invest in Arab stock markets, Middle East Executive Reports 25, 6-10.

Erdem, C., Arslan, C. K., \& Sema Erdem, M. (2005). Effects of macroeconomic variables on Istanbul stock exchange indexes. Applied Financial Economics, 15(14), 987-994.

Ghozali, I. (2013). Aplikasi analisis multivariate dengan program SPSS. Badan Penerbit Universitas Diponegoro.

Hasibuan, M., \& Manajemen, S. P. (2009). Dasar, Pengertian, dan Masalah, Edisi Revisi, Jakarta: PT. Bumi Aksara.

Hussin, M. Y. M., Muhammad, F., Hussin, M. A., \& Razak, A. A. (2012). The relationship between oil price, exchange rate and Islamic stock market in Malaysia. Research Journal of Finance and Accounting, 3(5), 83-92.
Jatiningsih, O. \& Musdholifah.(2007). Pengaruh Variabel Makroekonomi terhadap Indeks Harga Saham Gabungan di Bursa Efek Jakarta. Jurnal Aplikasi Manajemen, 5(1), 18-25.

Kandir, S. Y. (2008). Macroeconomic variables, firm characteristics and stock returns: Evidence from Turkey. International research journal of finance and economics, 16(1), 35-45.

Kewal, S. S. (2012). Pengaruh inflasi, suku bunga, kurs, dan pertumbuhan PDB terhadap indeks harga saham gabungan. Jurnal Economia, 8(1), 53-64

Mauliano, D. A. (2009). Analisis Faktor-Faktor yang Mempengaruhi Pergerakan Indeks Harga Saham Gabungan (IHSG) di Bursa Efek Indonesia. Universitas Gunadarma, Depok.

Mulyani, (2014). Analisis Pengaruh Inflasi, Suku Bunga, Nilai Tukar Rupiah, Dan Produk Domestik. Jurnal Bisnis dan Manajemen Eksekutif, Vol. 1 No. 1.

Rusliati, E., \& Fathoni, S. N. (2011). Inflasi, Suku Bunga Deposito dan Return Pasar terhadap Return Saham pada Industri Barang Konsumsi yang Terdaftar di BEI 2006-2009. Jurnal Bisnis dan Akuntansi, 13(2), 107-118.

Sekaran, U. (2011). Research Methods for business Edisi I and 2. Jakarta: Salemba Empat

Tandelilin, E. (2011). Analisis investasi dan manajemen portofolio. PT BPFE,Yogyakarta.

Usman, H., \& Akbar, S. (2003). Purnomo, Metodologi Penelitian Sosial Cet. IV. 